Western North American Naturalist 70(1), (C) 2010, pp. 121-125

\title{
PLOVERS BREEDING IN THE HIGHLANDS OF JALISCO, AGUASCALIENTES, ZACATECAS, AND SAN LUIS POTOSÍ, CENTRAL MÉXICO
}

\author{
Jaime Luévano ${ }^{1}$, Eric Mellink1,3, and Mónica Riojas-López ${ }^{2}$
}

\begin{abstract}
From April to July 2008, we surveyed for breeding plovers at 32 sites in the semiarid highlands of Jalisco, Aguascalientes, Zacatecas, and San Luis Potosí, in the Central Mexican High Plateau. We documented evidence or presumption of breeding Snowy Plovers (Charadrius alexandrinus) at 3 sites, Killdeer (C. vociferus) at 15 sites, and Mountain Plovers (C. montanus) at 1 site. Our surveys showed that the region is important breeding ground for only the Killdeer. We documented an apparent breeding range extension of the Mountain Plover to slightly more than $200 \mathrm{~km}$ south of its previously known breeding range.
\end{abstract}

Key words: Snowy Plover, Mountain Plover, Killdeer, distribution, status, shorebirds.

In central México, the highlands of Jalisco, Aguascalientes, Zacatecas, and San Luis Potosí offer a semiarid landscape dotted with manmade reservoirs and some natural impoundments that vary in size and permanence of water. This region is known to be within the breeding range of Snowy Plovers (Charadrius alexandrinus) and Killdeer (C. vociferus) (Howell and Webb 1995, Page et al. 1995, Van Perlo 2006), but during the breeding season, no observations of other plovers existed for this region. Killdeer are well-known residents of the region, but breeding of Snowy Plovers was restricted to Laguna Salinas and Presa La Zacatecana (Howell and Webb 1994). We assessed the presence of plovers, especially the presence of Snowy Plovers, breeding in the highlands of central México from April to July 2008.

The surveyed highlands include mountain ranges and endoreic drainages, which create some natural impoundments. Since the 18th century, numerous dams and cattle tanks have been built in this area. Visiting all or most of the water bodies to search for plovers was outside the scope of this survey, nor was that the best way to survey for the Snowy Plover, our target species. Moreover, most of these water bodies are seasonal, depending on rain from the previous year, and the majority of small seasonal wetlands are not depicted on available maps. However, given the strong preference of Snowy Plovers for saline flats, both along the Pacific coast of México (Mellink and Riojas-López 2005, Mellink et al. 2009) as well as in the continent's interior (i.e., Great Salt Lake, UT; Page et al. 1995), we used such flats as a starting point for our reconnaissance. We based our survey on historical information about the "salinas" (salt extraction facilities) that existed during colonial times (16th to 18th century), when all large or medium salt flats were used for the production of salt, which was required for the nearby silver mines (Ewald 1985).

We traveled extensively between these salt flats, taking different routes when possible and examining most smaller salt flats and impoundments we encountered. Sites surveyed included endoreic natural water bodies, former and current salinas, artificial impoundments either with masonry or with earthen dams, and small ponds. If a site was near the road and had some water, we usually examined it. Otherwise, we based our decision to examine a site on logistical considerations (e.g., time of day, difficulty of access, pending schedule). Altogether, we explored 32 sites (Fig. 1; Appendix 1). Since our surveys were nonrandom, we cannot extrapolate our data to the entire area.

We explored sites in 3 ways, depending on their size. Small sites (approximately $<1 \mathrm{ha}$ ) we surveyed from a single vantage point. Mid size sites (approximately 1-5 ha) we surveyed

${ }^{1}$ Departamento de Biología de la Conservación, Centro de Investigación Científica y de Educación Superior de Ensenada, Baja California. Carretera Tijuana-Ensenada, Km. 107, Ensenada, B.C. México. International mailing address: CICESE, Box 434844, San Diego, CA 92143-4844.

${ }^{2}$ Departamento de Ecología, Centro Universitario de Ciencias Biológicas y Agropecuarias, Universidad de Guadalajara, Km. 15.5 carretera a Nogales, 45100 Zapopan, Jalisco, México.

3Corresponding author. E-mail: emellink@cicese.mx or emellink@gmail.com 


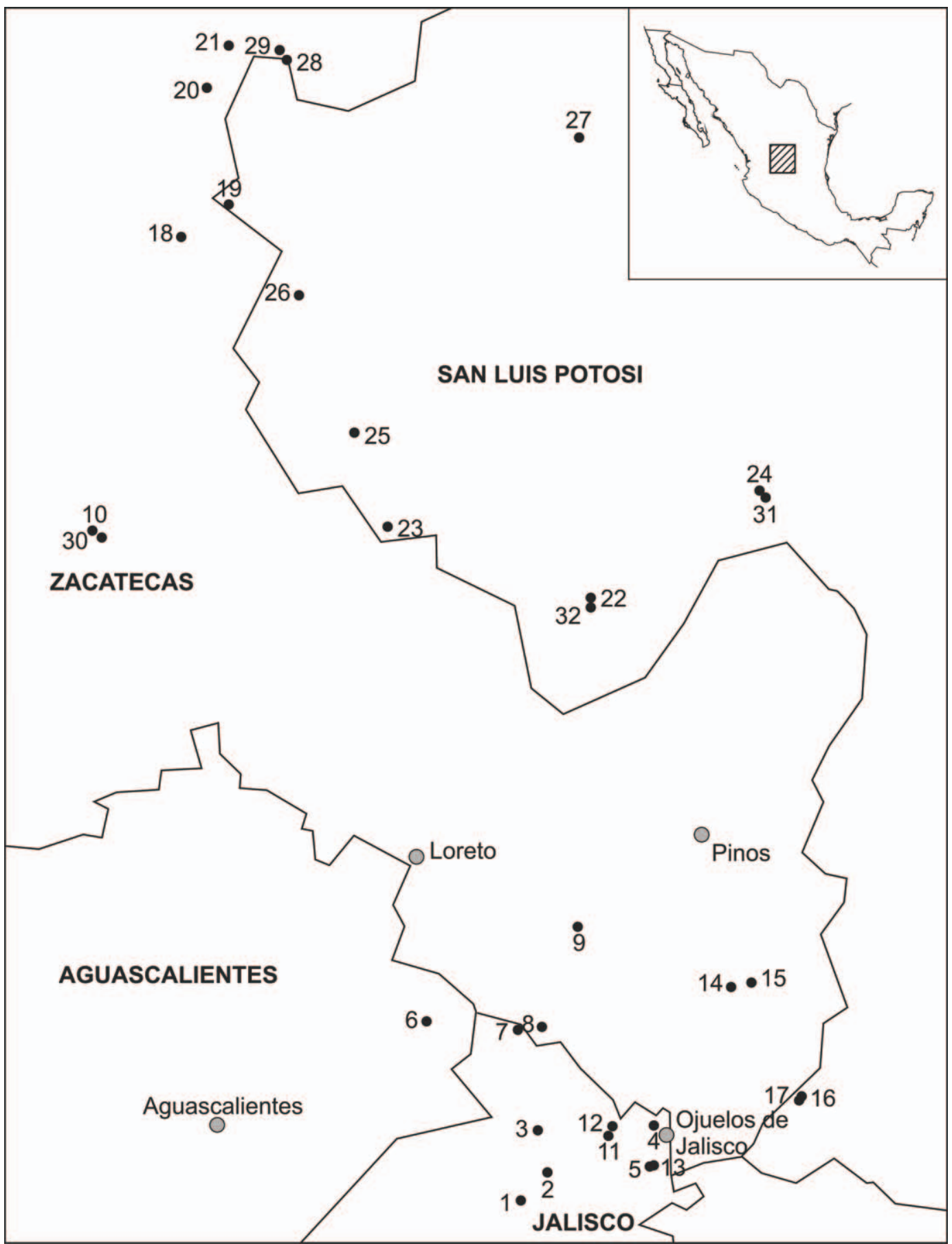

Fig. 1. Location of 32 sites surveyed in 2008 for breeding plovers in the highlands of Jalisco, Aguascalientes, Zacatecas, and San Luis Potosí, central México. 
by walking throughout them. Large sites (approximately $>5$ ha) we drove through slowly, in zigzags, stopping every $200-300 \mathrm{~m}$ to make a $180^{\circ}$ scan. In all surveys, we used binoculars and spotting scopes as visual aids.

We documented 28 species of waterbirds at 21 sites (Appendix 2). Only 3 of these species were plovers (Snowy Plover, Killdeer, and Mountain Plover [C. montanus]) and had enough evidence to suggest nesting.

We recorded Snowy Plovers at Salina Santa María (1 male), Laguna Salinas (1 male), and El Barril (5 males, 4 females, 4 unsexed individuals)—all foraging at the mudflat-water interface. All individuals that we could see well were in alternate plumage; we searched for but did not locate nests. No confirmed reports exist of the species oversummering in the region; and the time of year, plumage condition, and previous evidence of breeding (Howell and Webb 1994) suggest that they bred, or attempted to breed, at the localities where we found them. Of the 2 Snowy Plover breeding sites in our study area reported by Howell and Webb (1994), we found the species only at one: Laguna Salinas. The other locality, La Zacatecana, was dry and had been converted to agriculture.

We documented Killdeer at El Llavero Dam (5 individuals), a dam by La Paz (4), a dam at Rancho Viejo (10), water tanks \#1 and \#2 near Matancillas (6 and 1, respectively), a dam and water tank at Rancho Santo Domingo (several on different occasions in the recent past); a dam by Pilotos (3), a reservoir between La Estrella and Paso Blanco (2), a dam near El Remanente (1), a dam by Campos (1), a roadside pool (1), El Barril (5), and oxidation sewage ponds by Salinas de Hidalgo (5). At most locations, Killdeer exhibited distractive behavior; and at both the sewage pond by Salinas de Hidalgo and El Llavero dam, we saw one juvenile. Our data are concordant with the species being considered a widespread resident. Killdeer were present and exhibited distractive behavior even at some sites with human and cattle presence.

We found 2 Mountain Plovers at El Tapado, San Luis Potosí-a large, dry endoreic lagoon, which formerly held a salina. This area was a salt flat with sparse, low halophytic shrubs. The area surrounding the lagoon was a low, overgrazed grassland with abundant shrubs. We could not get close enough to discern the sex of the individuals, but they performed courtship-like movements and distractive behavior, including calls (Graul 1974, 1975, Knopf 1996). This habitat's characteristics, the Mountain Plovers' behavior, and the permanency of the site suggested breeding at this location. The nearest-known breeding location for this species is in northeastern México (Knopf and Rupert 1999, González-Rojas et al. 2006), slightly over $200 \mathrm{~km}$ to the north, over the Mexican Plateau. From our surveys, it seems evident that our study area has no large populations of Mountain Plovers, but our record suggests a need to survey other potential nesting locations for this species in the southern Chihuahuan Desert.

No previous study exists with which to compare our data. The data of Mellink and Valenzuela (1991) focused on wintering birds at sites that held water. Howell and Webb (1994) reported observations at 2 sites within our study area, but only for Snowy Plovers. Judging from the location of their sites, it appears that Howell and Webb (1994) did not survey sites away from the then-existing highways - understandably, since dirt roads in the region were quite bad at that time.

Although we might have missed some birds in sites not surveyed, we are confident that our data show that the highlands region probably does not harbor large numbers of plovers, other than Killdeer. Snowy Plovers were found sparingly, and given that we reviewed most potential sites, further surveys are unlikely to document large numbers. Snowy Plover numbers and the sites used by Snowy Plovers could vary from year to year depending on the presence of water, humans, and livestock. However, except perhaps at El Barril, there seems to be little opportunity for management to enhance their numbers. In this region, the salinas, unlike those along the southern Pacific coast of México (Mellink et al. 2009), do not provide suitable conditions for Snowy Plovers because they consist of salt pans with vertical walls, often lined with stones. Some old, semideteriorated pans can be used by Snowy Plovers, as we recorded at the Salina de Santa María. Salinas, current or past, are useful indicators, however, of large salt flats that can provide adequate nesting habitat for Snowy Plovers if water is present.

El Barril should be surveyed in greater detail to monitor use by Snowy Plovers as well as by other waterbirds. Surveys should be 
conducted throughout the breeding season and should include especially Laguna de Cruces in southwestern San Luis Potosí, which appears suitable for Snowy Plovers.

Killdeer are a common, widespread breeder in the region, capable of tolerating the presence of humans and livestock but apparently requiring free-standing water. We found them close to humans and domestic animals and did not find evidence of any problems with conserving Killdeer in the region.

Our finding of Mountain Plovers in the region and the presumed extension of their breeding range point to the need of searching for this species at other potential sites in the southern Chihuahuan Desert. One such site would be the prairie dog (Cynomys mexicanus) colony at El Manantial in northern San Luis Potosí. Further surveys at El Tapado, the site of our current record, should also be performed.

This work was funded by the U.S. Fish and Wildlife Service, Division of Migratory Bird Management, through a grant to Eduardo Palacios, to survey for Snowy Plovers in the interior of México. The grant was administered by PRONATURA, at the La Paz office. Francisco Javier Ponce assisted in figure preparation. Eduardo Palacios and 2 anonymous reviewers helped improve this article. Our gratitude to all of them.

\section{Literature Cited}

EwaLD, U. 1985. The Mexican salt industry, 1560-1980; a study in change. G. Fischer, Stuttgart and New York.

González-Rojas, J.I., M.A. Cruz Nieto, O. Ballesteros-Medrano, and I. Ruvalcaba-Ortega. 2006. First breeding record of a Mountain Plover in

APPENDIX 1. Sites surveyed in 2008 for breeding plovers in the highlands of Jalisco, Aguascalientes, Zacatecas, and San Luis Potosí, central México. Approximate area size (in hectares, derived from satellite images) and dates of visit are given after elevation.

\footnotetext{
Masonry dams

1. El Llavero, Jalisco $\left(21.76914^{\circ} \mathrm{N}, 101.81959^{\circ} \mathrm{W}, 2082\right.$ m, 24 ha, 31 May 2008). Little water; dry mudflats and some grassy patches. Livestock and people present. 2. La Paz, Jalisco $\left(21.82138^{\circ} \mathrm{N}, 101.77002^{\circ} \mathrm{W}, 2131 \mathrm{~m}, 5\right.$ ha, 31 May 2008). Little water and narrow mudflats. Livestock grazing, and people fishing. 3. Rancho Viejo, Jalisco $\left(21.87144^{\circ} \mathrm{N}, 101.78798^{\circ} \mathrm{W}, 2132 \mathrm{~m}, 20\right.$ ha, 2 May 2008). Several hectares covered by water, surrounded with mudflats and grassy cover. Isolated location and "protected" from visitors by bullfighting cattle. Light grazing. 4. Ojuelos
}

Nuevo Leon, Mexico. Wilson Journal of Ornithology 118:81-84.

Graul, W.D. 1974. Vocalizations of the Mountain Plover. Wilson Bulletin 86:221-229.

1975. Breeding biology of the Mountain Plover. Wilson Bulletin 87:6-31.

Howell, S.N.G., AND S. WebB. 1994. Occurrence of Snowy and Collared Plovers in the interior of Mexico. Western Birds 25:146-150.

. 1995. A guide to the birds of Mexico and northern Central America. Oxford University Press, New York, NY.

KNopf, F.L. 1996. Mountain Plover (Charadrius montanus). In: A. Poole and F. Gill, editors, The birds of North America, No. 211. Academy of Natural Sciences, Philadelphia, PA, and American Ornithologists' Union, Washington, DC. $16 \mathrm{pp}$.

KNOPF, F.L., AND J.R. RUPERT. 1999. A resident population of Mountain Plover Charadrius montanus in Mexico? Cotinga 11:17-19.

MELLinK, E., AND M.E. Riojas-López. 2005. New breeding localities for the Snowy Plover in western Mexico. Western Birds 36:141-143.

Mellink, E., M. Riojas-López, and J. Luévano. 2009. Coastal breeding locations of seven Charadriiformes from Jalisco to Guerrero, southern Mexico. Waterbirds 32:44-53.

Mellink, E., and S. Valenzuela. 1991. Estudio preliminar sobre los habitats acuáticos y ribereños de la Planicie Occidental Potosina y sugerencias para su manejo. Agrociencia, serie Recursos Naturales Renovables 1:59-71.

Page, G.W., J.S. Warriner, and P.W.C. Paton. 1995. Snowy Plover (Charadrius alexandrinus). In: A. Poole and F. Gill, editors, The birds of North America, No. 154. Academy of Natural Sciences, Philadelphia, PA, and American Ornithologists' Union, Washington, DC.

Van Perlo, B. 2006. Birds of Mexico and Central America. Princeton Illustrated Checklists. Princeton University, Princeton and Oxford.

Received 15 May 2009

Accepted 24 September 2009

de Jalisco, Jalisco $\left(21.88879^{\circ} \mathrm{N}, 101.57174^{\circ} \mathrm{W}, 2198 \mathrm{~m}, 30\right.$ ha, 29 May 2008). Dry. Crisscrossed by roads. 5. Rancho Santo Domingo, Jalisco $\left(21.82349^{\circ} \mathrm{N}, 101.62121^{\circ} \mathrm{W}, 2300\right.$ m, 2 ha, 10 April 2008). Dates from colonial times. Little water. No livestock or people but a few horses watering. 6. Pilotos, Aguascalientes $\left(22.03312^{\circ} \mathrm{N}, 101.96692^{\circ} \mathrm{W}, 2035\right.$ $\mathrm{m}, 15$ ha, 22 May 2008). Little water and muddy flanks. Heavy presence of people, livestock, and dogs. 7. Campos, Zacatecas $\left(22.02149^{\circ} \mathrm{N}, 101.8302^{\circ} \mathrm{W}, 6\right.$ ha, 26 May 2008). Abundant water. Goats, herders, and dogs present. 8. Montoro, Zacatecas $\left(22.04322^{\circ} \mathrm{N}, 101.82563^{\circ} \mathrm{W}, 1.5\right.$ ha, 2 May 2008). Rocky substrate, with deeper water than other sites, and a very narrow mudflat. People fishing. 9. El Remanente, Zacatecas $\left(22.17485^{\circ} \mathrm{N}, 101.73028^{\circ} \mathrm{W}\right.$, $2240 \mathrm{~m}, 1.2$ ha, 8 May 2008). Rocky substrate, with some deep water and narrow mudflats. Light human and livestock use. 10. La Zacatecana, Zacatecas $\left(22.73497^{\circ} \mathrm{N}\right.$, 
$102.4693^{\circ} \mathrm{W}, 120$ ha, 15 July 2008). Dry and plowed for farming. Much livestock and human use of the area. Surveyed by Howell and Webb (1994) at a time when the area had water

\section{Earthen dams}

11. Reservoir 1, Matancillas, Jalisco $\left(21.89524^{\circ} \mathrm{N}\right.$, $101.67187^{\circ} \mathrm{W}, 2144 \mathrm{~m}, 7 \mathrm{ha}, 31$ May 2008). Little water; surrounded by dry, cracked mud. People and livestock present. 12. Reservoir 2, Matancillas, Jalisco $\left(21.89114^{\circ} \mathrm{N}\right.$, $101.66902^{\circ} \mathrm{W}, 2148 \mathrm{~m}, 22$ ha, 31 May 2008). Similar to site 11. 13. Rancho Santo Domingo, Jalisco $\left(21.82257^{\circ} \mathrm{N}\right.$, $101.61477^{\circ} \mathrm{W}, 2300 \mathrm{~m}, 0.3 \mathrm{ha}, 10$ April 2008). Some water; grassy edges. Light human and livestock use. 14. Reservoir near La Estrella, Zacatecas $\left(22.08462^{\circ} \mathrm{N}, 101.51352^{\circ} \mathrm{W}\right.$, $2274 \mathrm{~m}, 3$ ha, 9 May 2008). Some water; exposed mudflats. Used by livestock. 15. Reservoir between La Estrella and Paso Blanco, Zacatecas $\left(22.0928^{\circ} \mathrm{N}, 101.4767833^{\circ} \mathrm{W}\right.$, $2169 \mathrm{~m}, 3$ ha, 9 May 2008). Some water; exposed mudflats. Used by livestock. 16. Reservoir 1, Santa Rosa de Gallinas, San Luís Potosí $\left(21.96206^{\circ} \mathrm{N}, 101.40373^{\circ} \mathrm{W}, 2147\right.$ $\mathrm{m}, 0.5$ ha, 30 May 2008). Some water, surrounded by dry, mid-textured soil. The site is in the midst of a rain-fed agricultural area; some livestock and human presence. 17. Reservoir 2, Santa Rosa de Gallinas, San Luís Potosí $\left(21.95863^{\circ} \mathrm{N}, 101.39959^{\circ} \mathrm{W}, 2141 \mathrm{~m}, 0.2 \mathrm{ha}, 30\right.$ May 2008$)$. Similar to site 16

\section{Endoreic lakes}

18. Chupaderos, Zacatecas $\left(23.16239^{\circ} \mathrm{N}, 102.31939^{\circ} \mathrm{W}\right.$, 1973 m, 150 ha, 30 April 2008). Dry, with low, sparse herbaceous vegetation. Heavy use by livestock. 19. El Agrito, Zacatecas $\left(23.18655^{\circ} \mathrm{N}, 102.26652^{\circ} \mathrm{W}, 1965 \mathrm{~m}, 18\right.$ ha, 30 April 2008). Dry, with an old small salt operation that has not been active for about a century. This appears to be the historical salt operation of Laguna San Cosme. No human or livestock presence. 20. La Colorada, Zacatecas $\left(23.37041^{\circ} \mathrm{N}, 102.15096^{\circ} \mathrm{W}, 1920 \mathrm{~m}, 7\right.$ ha, 30 April 2008). Dry, with low, sparse vegetation. A recent salt-producing facility whose construction appears to have been suspended before completion. 21. Santa María, Zacatecas $\left(23.38809^{\circ} \mathrm{N}, 102.18816^{\circ} \mathrm{W}, 1917 \mathrm{~m}, 23\right.$ ha, 30 April 2008). Dry, with low, sparse vegetation. No signs of heavy livestock or human use. 22. Salinas, San Luís Potosí $\left(22.64416^{\circ} \mathrm{N}\right.$ 101.70941 ${ }^{\circ} \mathrm{W}, 2032 \mathrm{~m}, 300 \mathrm{ha}, 30$ April 2008). This lagoon harbored the most important salina during colonial times, and it still produces some salt commercially. Some roads crisscross it, but overall the lagoon is seldom visited by people and is not used by livestock. Surveyed by Howell and Webb (1994). Winter waterbirds at the salt works were surveyed by Mellink and Valenzuela (1991). 23. El Salado, San Luís Potosí $\left(22.70375^{\circ} \mathrm{N}, 102.03313^{\circ} \mathrm{W}, 2038\right.$ $\mathrm{m}, 30$ ha, 3 June 2008). Dry. Low human and livestock use. 24. El Tapado, San Luís Potosí $\left(22.78679^{\circ} \mathrm{N}, 101.43882^{\circ} \mathrm{W}\right.$, 1943 m, 500 ha, 7 May 2008, 12 May 2008, 24 May 2008, 3 June 2008). Dry, with patches of halophytic herbs and saltgrass (Distichlis spicata). During colonial times, the area harbored an important salt-producing facility, now virtually abandoned. No people visit the area, and no livestock were present. 25. Salitral de Carrera, San Luís Potosí $\left(22.86962^{\circ} \mathrm{N}, 102.07216^{\circ} \mathrm{W}, 2029 \mathrm{~m}, 340\right.$ ha, 3 June 2008). Dry, with halophitic vegetation. 26. El Barril, San Luís Potosí $\left(23.08199^{\circ} \mathrm{N}, 102.15767^{\circ} \mathrm{W}, 1968 \mathrm{~m}\right.$, 180 ha, 3 June 2008). The area receives some freshwater from artesian wells probably during the entire year and is filled during the rainy season by runoff. One small, isolated marsh with emergent plants, and an area with standing water, surrounded by wet mudflats; the rest, entirely dry. Light human presence. 27. Santo Domingo, San Luís Potosí $\left(23.31375^{\circ} \mathrm{N}, 101.7231667^{\circ} \mathrm{W}, 1968 \mathrm{~m}, 750 \mathrm{ha}, 28\right.$ May 2008). Dry, with many roads crisscrossing the area.

\section{Active salinas}

28. Laguna Saldivar, Zacatecas $\left(23.37461^{\circ} \mathrm{N}, 102.18086^{\circ} \mathrm{W}\right.$, $1924 \mathrm{~m}, 95$ ha, 30 April 2008). The salina seemed recently established. Steep banks of the channel and vertical sides of the salt pans prevent use by shorebirds. 29. Santa María, Zacatecas $\left(23.39427^{\circ} \mathrm{N}, 102.19596^{\circ} \mathrm{W}, 1966 \mathrm{~m}, 12\right.$ ha, 30 April 2008). During colonial times, the area harbored a very large salt-producing facility. Only a small part of it remains in operation. Steep banks of the channel and vertical sides of the salt pans prevent use by shorebirds.

Other

30. Marsh within the La Zacatecana, Zacatecas $\left(22.73743^{\circ} \mathrm{N}, 102.47384^{\circ} \mathrm{W}, 3\right.$ ha, 15 July 2008$)$. Small marsh with emergent vegetation. Fenced off, but heavy human and livestock use adjacent. 31. Roadside pool, San Luís Potosí $\left(22.78739^{\circ} \mathrm{N}, 101.43742^{\circ} \mathrm{W}, 0.5\right.$ ha, 15 May 2008). Resulted from road construction; grassy borders. 32. Oxidation sewage ponds by Salinas de Hidalgo, San Luís Potosí $\left(22.6402^{\circ} \mathrm{N}, 101.70452^{\circ} \mathrm{W}, 2037 \mathrm{~m}, 2\right.$ ha, 3 June 2008). Permanent water, shallow, and grassy banks.

APPENDIX 2. Waterbirds recorded in spring 2008 in the highlands of Jalisco, Aguascalientes, Zacatecas, and San Luis Potosí, central México. The numbers in parentheses refer to the localities in Appendix 1.

\begin{tabular}{ll}
\hline Bird group & Species and locations \\
\hline Cormorants & Phalacrocorax auritus $(1,3)$ \\
Grebes & Podiceps nigricollis $(15)$, Podilymbus podiceps $(3,5,9,13,17)$ \\
Waterfowl & Anas americana $(5,13,26)$, Anas clypeata $(3,5,13)$, Anas crecca $(2)$, Anas cyanoptera $(3,5)$, \\
& Anas diazi $(2,3,5,6,11,12,13,15,17,26,30,31,32)$, Anas discors $(3,5)$, Oxyura jamaicensis $(9)$ \\
Herons and egrets & Bubulcus ibis $(3,5)$, Egretta alba $(5,11,12,13,17)$, Egretta thula $(6)$, Nycticorax nycticorax \\
& $(3,12)$, Plegadis chihi $(11,12,30)$ \\
Plovers & Charadrius alexandrinus $(22,26,29)$, Charadrius montanus $(24)$, Charadrius vociferus $(1,2$, \\
& $3,5,6,7,9,11,12,13,15,26,31,32)$ \\
Stilts and avocets & Himantopus mexicanus $(11,32)$, Recurvirostra americana $(11,12,28,29,32)$ \\
Shorebirds & Numenius americanus $(26)$, Calidris mauri $(3,9)$, Calidris minutilla $(9,26)$, Calidris sp. $(29)$ \\
Gulls & Larus delawarensis $(26)$, Larus pipixcan $(26)$ \\
Coots & Fulica americana $(2,3,5,6,8,11,13,26)$ \\
Phalaropes & Phalaropus tricolor $(29)$ \\
\hline
\end{tabular}

